\title{
The Influence of DNA Solution on Dipole Antenna Purcell Factor Spectra
}

\author{
Olcay Yiğit ${ }^{1}$, Fadıl Kuyucuoğlu ${ }^{2 *}$, Yavuz Öztürk ${ }^{1}$ \\ ${ }^{I}$ Ege University, Faculty of Engineering, Department of Electrical and Electronics Engineering, İzmir, Turkey \\ ${ }^{2}$ Manisa Celal Bayar University, Faculty of Engineering, Department of Electrical and Electronics Engineering, \\ Manisa, Turkey \\ olcyygt@gmail.com@, *fadil.kuyucuoglu@cbu.edu.tr@, yavuz.ozturk@ege.edu.tr@ \\ Received date: 01.09.2020, Accepted date: 13.04.2021
}

\begin{abstract}
In this study, deoxyribonucleic acid (DNA) solution effect on the Purcell factor of an electric dipole antenna was analyzed. Any antenna tuned to a resonance can be described as a radiator, and the effect of the environment on its radiation can be defined as Purcell factor. It is possible to determine the Purcell factor in terms of the real part of the antenna input impedance. Therefore, the Purcell factor of an antenna in the presence of pure water and DNA solution was calculated through measuring the input impedance of a dipole antenna with resonance frequency of 9.6-11.6 GHz. The Purcell factor of the antenna was measured and analyzed in the frequency range 5-16 GHz for the samples placed at $5 \mathrm{~mm}$ to $20 \mathrm{~mm}$ from the antenna. The frequency bands where the maximum DNA sensitivity of Purcell factor occurs were determined.
\end{abstract}

Keywords: Dipole antenna, DNA solution, Purcell effect, Purcell factor

\section{DNA Çözeltisinin Dipol Anten Purcell Faktör Spektrumlarına Etkisi}

\section{$\ddot{O} \mathbf{z}$}

Bu çalışmada, deoksiribonükleik asit (DNA) çözeltisinin bir elektrik dipol antenin Purcell faktörü üzerindeki etkisi analiz edilmiştir. Bir rezonans frekansına ayarlanmış herhangi bir anten bir yayıcı olarak tanımlanabilir ve çevreden kaynaklı anten radyasyonu üzerindeki değişim Purcell faktörü olarak tanımlanır. Purcell etkisini anten giriş empedansının gerçek kısmı cinsinden belirlenebilir. Bu nedenle, DNA çözeltisi ve saf su varlığında anten Purcell faktörü, 9.6-11.6 GHz rezonans frekansı bandı olan bir çift kutuplu antenin giriş empedansı ölçülerek hesaplandı. Antenin Purcell faktörü, antene $5 \mathrm{~mm}$ ila $20 \mathrm{~mm}$ mesafelerde yerleştirilmiş örnekler ile 5-16 GHz frekans aralığında ölçüldü ve analiz edildi. Purcell faktörünün maksimum DNA duyarlılığının oluştuğu frekans bantları belirlendi.

Anahtar Kelimeler: Dipol anten, DNA çözeltisi, Purcell etkisi, Purcell faktörü

\section{INTRODUCTION}

The Purcell effect was first described by E.M. Purcell in 1946. This effect is defined as a modification of the spontaneous emission lifetime of a quantum source induced by interacting with the environment (Purcell, 1946). This effect has been used for measuring nano-sized structures or biological processes with participation of large molecules in recent research (Acuna et al., 2012; Krosnak et al., 2015; Kaushal et al., 2020).
DNA as one of the large biomolecules is highly investigated for its optical and electrical properties in many studies. Although different DNA conductance values were obtained in different papers, there are many studies show that the DNA exhibits conducting behavior in solutions (Sönmezoğlu et al., 2010; Chao et al., 2016; Dekker and Ratner, 2001; Xu et al., 2004; Ozturk et al., 2017). Initial studies have shown that DNA tends to absorb microwave radiation in the $\mathrm{kHz}$ range (Sakamoto et al., 1979; Bukhari et al., 2018). Research on microwaves on bacteria, viruses and 
DNA effects were carried out since the 1960's and included research on several effects such as heating, dielectric dispersion (Webb and Booth, 1969; Emilova et al., 2014; Mehrotra et al., 2019). The similarity of electromagnetic field interactions over relatively wide frequency ranges suggest that DNA behaves like a fractal antenna (Martin and Reba, 2011). Also in microwave range, there are several studies to investigate DNA solutions with resonator (Lee et al., 2010), RF interferometer (Cui et al., 2014), dielectric spectroscopy up to $110 \mathrm{GHz}$ frequency range (Emilova et al., 2014). These studies show that both electrical and dielectric properties of water changes with addition of DNA in solution (Lee et al., 2010; Cui et al., 2014; Ermilova et al., 2014).

The previous studies on DNA have been focused on transmission or absorption dependent measurements (Cui et al., 2014; Ermilova et al., 2014). Novelty of this study is the use of the input impedance of the antenna to calculate the Purcell effect of a dipole antenna in the presence of DNA solution. The dipole antenna was designed to have a resonance frequency range of 9.6-11.6 GHz. The dipole antenna was chosen because of its easy design and its omnidirectional radiation pattern. The results obtained from experiments were used for spectral analysis of Purcell factor in the presence of DNA in the water. Also Purcell effect sensitivity is investigated in terms of distance of DNA solution to dipole antenna.

\section{MATERIAL AND METHOD Purcell Factor}

The theory given in the study of Krasnok et al., is summarized in the following section (Krosnak et al., 2015). A radiating electric dipole antenna with of an arbitrary passive object is given in Figure 1. The total electric field generated by the antenna at its origin $E(r)$ can be written as $E(r)=E_{1}(r)+E_{2}(r)$, where $E_{1}(r)$ is the field generated by the dipole in the absence of the arbitrary object and $E_{2}(r)$ is the field scattered by the object. The total power delivered to the environment can be written as

$$
P=P_{1}+P_{2}
$$

(where $\mathrm{P}_{1}$ is the power radiated by the dipole in the absence of the object and $\mathrm{P}_{2}$ is defined as

$$
P_{2}=\frac{1}{2} \operatorname{Re}\left[E_{2}(r) \cdot \int j_{1}{ }^{*} d V\right]
$$

where $\mathrm{j}_{1}$ is the current density on the antenna. Purcell factor $\mathrm{F}$ can be written in terms of powers defined in Equation 1 and 2 as in Equation 3.

$$
F=\frac{P_{1}+P_{2}}{P_{1}}
$$

From the general antenna theory, short dipole radiation resistance equals its input impedance, when the dissipative losses are neglected. Hence the Purcell factor is defined as (Krosnak and et al., 2015)

$$
\mathrm{F}=\frac{R_{\text {in }}}{R_{0, \text { in }}}=\frac{\operatorname{Re} Z_{\text {in }}}{\operatorname{Re} Z_{0, i n}}
$$

where $R_{\text {in }}$ is the real part of the antenna input impedance at the presence of arbitrary object and $\mathrm{R}_{0, \text { in }}$ is the real part of the antenna input impedance at the absence of the arbitrary object.

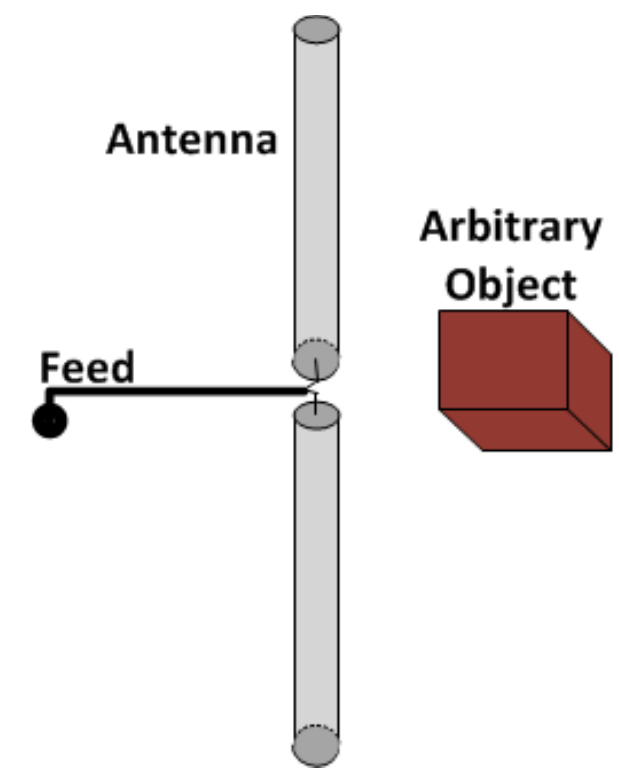

Figure 1. Illustration of antenna configuration with an arbitrary object.

\section{Experimental Setup}


A dipole antenna which resonates at 9.611.6 $\mathrm{GHz}$ bandwidth was designed for the experiments. The antenna was designed via soldering two pieces of solid metal pieces with cross section area of $0.4 \mathrm{~mm}^{2}$ and length of $7.5 \mathrm{~mm}$ to a SMA connector. The solution was prepared by mixing $0.03 \mathrm{mg}$ herring sperm DNA (D3159, Sigma Aldrich) into the $10 \mathrm{ml}$ distilled pure water. DNA solution was placed in front of the dipole antenna with d distance of $5,10,15$, and $20 \mathrm{~mm}$ for each measurement as shown in Figure 2 (a) and (b).$S_{11}$ parameter and $Z_{11}$ impedance of the antenna were measured using ZVA-24 model network analyzer.

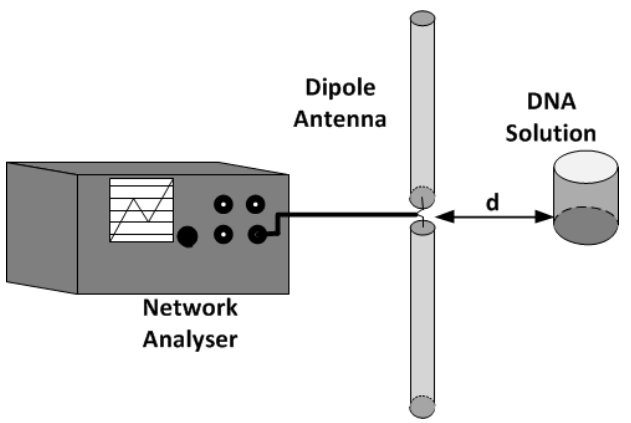

(a)

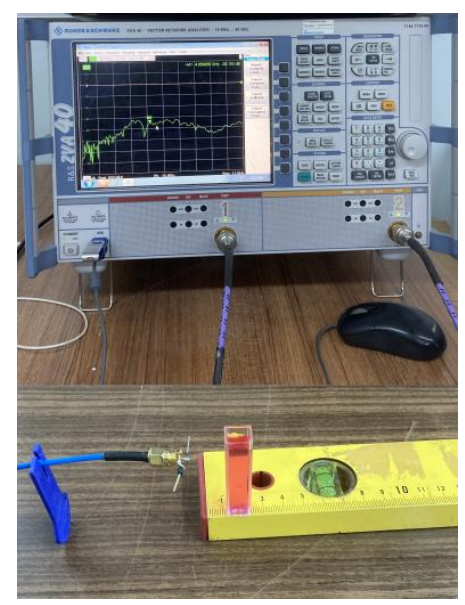

(b)

Figure 2. (a) Illustration of experimental setup b) Experimental setup

\section{RESULTS AND DISCUSSION}

Return loss $\mathrm{S}_{11}$ measurement result of the dipole antenna is shown in Figure 3. Resonant frequency band of the antenna is determined as 9.611.6 GHz where the $S_{11}$ is lower than $-10 \mathrm{~dB}$.

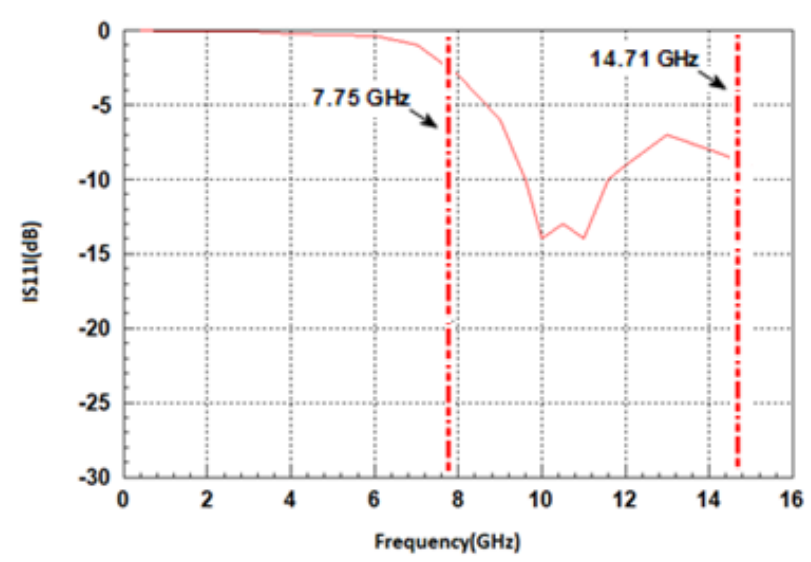

Figure 3. Return loss values (S11 parameter) of dipole antenna versus frequency

The real part of the antenna input impedance was measured to calculate the Purcell factor. The measurements were taken in free space, and in the presence of the pure water or DNA solution. Purcell factors were calculated from the measurements in frequency domain at distances $5,10,15,20 \mathrm{~mm}$ by using Equation 4. Figure 4 shows Purcell factors of the dipole antenna at the frequency band of $6 \mathrm{GHz}$ to $16 \mathrm{GHz}$ for various distances in the presence of the pure water. It can be seen that when the distance is 5 $\mathrm{mm}$, the Purcell factor has higher optimum values than the other distances. In addition, maximum Purcell factor value of 1.24 and 0.84 at $7.75 \mathrm{GHz}$ and $14.71 \mathrm{GHz}$ is obtained at this distance, respectively. 


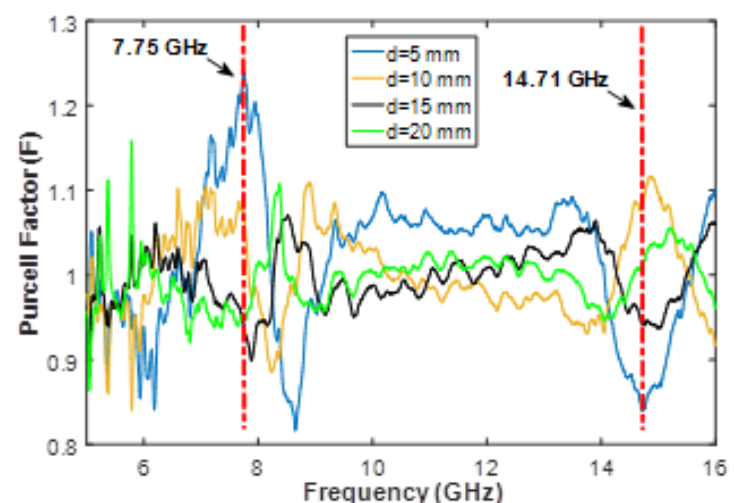

Figure 4. Purcell factor of dipole antenna versus frequency in the presence of water sample.

In Figure 5, the Purcell factor of the antenna with DNA sample versus frequency is given for the same various distance values. Purcell factor is decreased to 1.15 value for DNA solutions at 7.75 $\mathrm{GHz}$, which was 1.24 for the water. We can say that, when the distance is small around $5 \mathrm{~mm}$, variation of Purcell factor of DNA solution is higher when compared to other distances. At $5 \mathrm{~mm}$ distance, for the selected frequencies, the Purcell factor of DNA solution has lower values in comparison to that of water. DNA solution Purcell factor values are 1.15 and 0.87 at the 7.75 and 14.71 $\mathrm{GHz}$ frequencies for $5 \mathrm{~mm}$ distance, respectively.

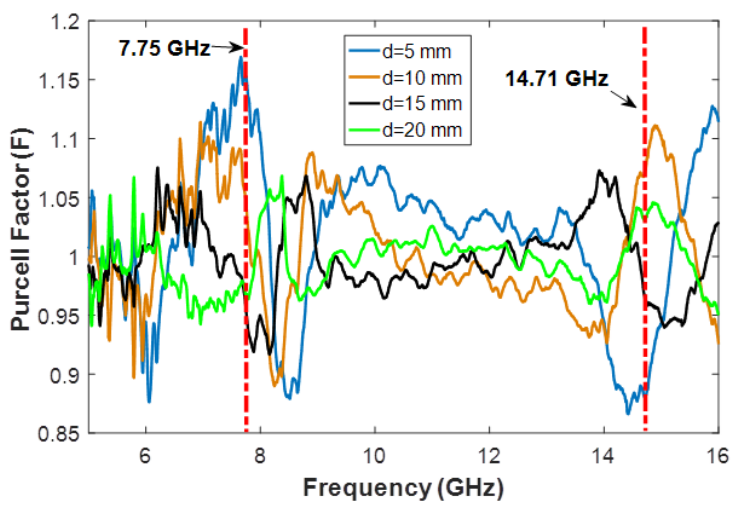

Figure 5. Purcell factor of dipole antenna versus frequency in the presence of DNA solution

Difference of the Purcell factors of $3 \mu \mathrm{g} / \mathrm{ml}$ DNA solution and the pure water is given in Figure 6. Optimum values of $\Delta \mathrm{F}$ are obtained when $\mathrm{d}=5$ $\mathrm{mm}$. In the resonance region of the dipole antenna, $\Delta \mathrm{F}$ values are below 0.05 and no clear information of DNA is observed. However, around $\pm 0.08 \pm 0.015$
$\Delta \mathrm{F}$ values were observed in the frequency ranges of 7.7-8.1 GHz, 13.6-14.1 GHz 14.9-15.7 GHz. These bands can be used to investigate DNA existence in water at $5 \mathrm{~mm}$ distance for the designed dipole antenna. The results of several works shows that the real part of electric relative permittivity of DNA solution decreases although the imaginary part increases as frequency increases in the frequency range of this study (Lee et al., 2010; Cui et al., 2014). The results of this study can be attributed to change of the dielectric properties of water with DNA.

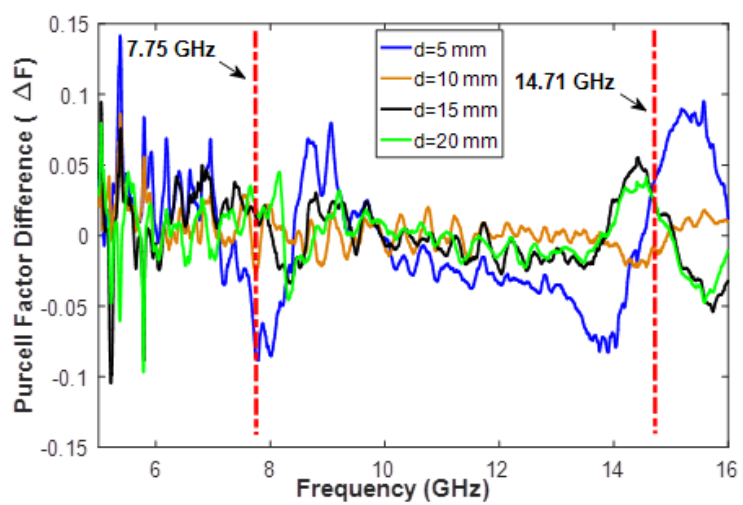

Figure 6. Purcell factor difference of DNA solution and water versus frequency.

\section{CONCLUSION}

Purcell effect of a dipole antenna in the presence of water and DNA solution is measured for various distances. It is seen that DNA solution has a decreasing effect on Purcell factor. Purcell factor difference between water and DNA solution of $3 \mu \mathrm{g} / \mathrm{ml}$ is calculated and around $8 \%$ change is observed at the frequency bands of 7.7-8.1 GHz, $13.6-14.1 \mathrm{GHz} 14.9-15.7 \mathrm{GHz}$. As a result it is found that these frequency bands can be used to analyze the DNA existence in water. Different DNA concentration analyses for different type of antennas are possible for the future work.

\section{CONFLICT OF INTEREST}

The Author report no conflict of interest relevant to this article

\section{RESEARCH AND PUBLICATION ETHICS STATEMENT}


The author declares that this study complies with research and publication ethics.

\section{REFERENCES}

Acuna, G. P., Möller, F. M., Holzmeister, P., Beater, S., Lalkens B., Tinnefeld P., 2012. Fluorescence enhancement at docking sites of dna-directed selfassembled nanoantennas. Science, 338:506-510

Bukhari, M. H., Batool, S., Raza, D. Y., Bagasra, O., Rizvi, A., Shah, A., Sultan, T., 2018. DNA electromagnetic properties and interactions-An investigation on intrinsic bioelectromagnetism within DNA. Electromagnetic biology and medicine, 37(3)169-174.

Chao, J., Zhu, D., Zhang, Y., Wang, L., Fan, C., 2016. DNA nanotechnology-enabled biosensors. Biosensors and Bioelectronics, 76:68-79.

Cui, Y., Li, J., Cao, W., Wang, P., 2014. Highly sensitive RF detection and analysis of DNA solutions. In 2014 IEEE MTT-S International Microwave Symposium (IMS2014), Tampa, Florida, USA, June 1-6.

Dekker C, Ratner M., 2001. Electronic properties of DNA. Physics World, 14(8) : 29.

Ermilova, E., Bier, F. F., Hölzel, R., 2014. Dielectric measurements of aqueous DNA solutions up to 110 GHz. Physical Chemistry Chemical Physics, 16(23):11256-11264.

Kaushal, S., Nanda, S. S., Samal, S., Yi, D. K., 2020. Strategies for the Development of Metallic Nanoparticle Based Label Free Biosensors and Their Biomedical Applications. ChemBioChem, 21(5): 576-600.

Krasnok, A. E. , Slobozhanyuk, A. P., Simovski, C. R., Tretyakov, S. A., Poddubny, A. N., Miroshnihenko, A.E. , Kivshar, Y. S. and Belov, P.A., 2015. An antenna model for the Purcell effect. Scientific Reports, 5(1):1-16.

Lee, H. J., Lee, H. S., Yoo, K. H., Yook, J. G., 2010. DNA sensing using split-ring resonator alone at microwave regime. Journal of Applied Physics, 108(1):014908.

Martin B. , Reba G., 2011. DNA is a fractal antenna in electromagnetic fields. International Journal of Radiation Biology,87:409-415

Mehrotra, P., Chatterjee, B., Sen, S., 2019. EM-wave biosensors: A review of RF, microwave, mm-wave and optical sensing. Sensors, 19(5):1013.

Ozturk, Y., Yildirim, B., Sekerin, K., \& Bayram, A., 2017. Quantized Conductance Measurement System for Liquids and Application to DNA Solution. Hittite Journal of Science and Engineering, 4(1), 51-55.

Purcell, E.M., 1946. Spontaneous emission probabilities at radio frequencies. Physical Review, 69:681.
Sakamoto, M., Hayakawa, R., Wada, Y., 1979. Dielectric relaxation of DNA solutions. III. Effects of DNA concentration, protein contamination, and mixed solvents. Biopolymers: Original Research on Biomolecules, 18(11): 2769-2782.

Sönmezoğlu, S. ,Sönmezoğlu, Ö.,Çankaya, G.,Yıldırım, A., Serin, N., 2010. Electrical characteristics of DNA-based metal-insulator-semiconductor structures. Journal of Applied Physics, 107(12):124518.

Webb, S. J., Booth, A. D., 1969. Absorption of microwaves by microorganisms. Nature, 222(5199):1199-1200.

Xu B, Zhang P, Li X, Tao N., 2004. Direct conductance measurement of single DNA molecules in aqueous solution. Nano letters, 4(6) (2004) 1105-1108 